\title{
Valorization of the essential oil of Myrtus communis by its use as a corrosion inhibitor of mild steel in acidic medium $1.0 \mathrm{M} \mathrm{HCl}$
}

\section{H. El Hartiti, ${ }^{1 *}$ A. Elmostaphi, ${ }^{1}$ M. Barrahi, ${ }^{1}$ M. Saadouni, ${ }^{2}$ R. Salghi, ${ }^{3}$ A. Zarrouk, ${ }^{4}$ B. Bourkhiss ${ }^{1}$ and M. Ouhssine ${ }^{1}$}

${ }^{1}$ Laboratory of Agro-physiology, Biotechnology, Environment and Quality, Department of Biology; Faculty of Sciences, University Ibn Tofail BP 133, 14000 Kénitra, Morocco

${ }^{2}$ Laboratory of Applied Chemistry \& Environment, ENSA, Ibn Zohr University, PO Box 1136, 80000 Agadir, Morocco

${ }^{3}$ Laboratory of Organic, Organometallic and Theoretical Chemistry, Faculty of Science, Ibn Tofail University, 14000 Kenitra, Morocco

${ }^{4}$ Laboratory of Materials, Nanotechnology and Environment, Department of Chemistry, Faculty of Sciences, Mohammed V University, PO Box 1014 Rabat, Morocco *E-mail: hajarelhartiti@gmail.com

\begin{abstract}
The green corrosion inhibitors serve recently as a source of environmentally friendly materials in the corrosive media. Herein, an environmentally friendly green inhibitor based on Myrtus communis oil, noted (MCO) was applied for corrosion mitigation of mild steel (MS) surface in $1.0 \mathrm{M} \mathrm{HCl}$ solution. The corrosion inhibition characteristics were examined applying weight loss and electrochemical (Electrochemical impedance spectroscopy and potentiodynamic polarization) techniques. The results obtained for MCO showed a good inhibition effect on the mild steel in the $1.0 \mathrm{M} \mathrm{HCl}$ solution. Based on the EIS examination, the inhibition efficiency was found to increase with a corresponding increase in the MCO concentration, and the best inhibition of $92 \%$ occurred at a MCO concentration of $2.5 \mathrm{~g} / \mathrm{L}$. The potentiodynamic studies revealed that investigated $\mathrm{MCO}$ acts as mixed type inhibitor, i.e. the corrosion suppression occurred via retardation of combined cathodic and anodic reactions. The weight loss analysis proved 93\% inhibition efficiency for the acid solution containing $2.5 \mathrm{~g} / \mathrm{L}$ of MCO. By enhancing the solution temperature, the steel resistance against corrosion decreased, and the efficiencies of $93,87,84$, and $82 \%$ were obtained at $303,313,323$, and $333 \mathrm{~K}$, respectively. Activation parameters were calculated and discussed. The studied inhibitor obeyed Langmuir's adsorption isotherm.
\end{abstract}

Keywords: corrosion, EIS, $\mathrm{HCl}$, mild steel, Myrtus communis, PDP.

Received: June 20, 2019. Published: December 3, 2019

doi: $\underline{10.17675 / 2305-6894-2019-8-4-16}$

\section{Introduction}

Corrosion affects most industrial sectors and can cost billions of dollars each year [1]. The industrial processes are exposed to the daily action of acids but sometimes also bases. They act as corrosive agents. However, acids play an important role in the industry, especially in 
cleaning systems in food industries, crude oil refining, acid pickling, industrial cleaning, acid scaling and petrochemical processes [2].

The corrosion of metals is a major problem that must find solutions for economic, safety and environmental reasons. It can be minimized by appropriate strategies that aim to quench, delay and completely stop anodic, cathodic or both reactions [3].

Most synthetic compounds have a good anticorrosive action, but most of them are highly toxic to humans and the environment. These inhibitors can cause temporary or permanent damage to the organ system such as kidneys, liver, or disrupt enzymatic systems in the body [4].

Organic molecules extracted from plants appear as an alternative tool in the field of corrosion inhibition because of their biodegradability, availability and non-toxicity. As a result, several researchers have focused on the potential use of these green inhibitors for about ten years [5-8].

Various natural substances have been tested as corrosion inhibitors of steel in acidic medium [9, 10]. Of these, the essential oils of Foeniculum vulgare [11], of cedar [12], lavender [13], thym [14], mint [15], Artemisia mesatlantica [16].

Based on the literature that we consulted, it appears that no study has been made on the anticorrosive activity of the essential oil of Myrtus communis. In this work, the corrosion of mild steel in hydrochloric acid was monitored in the absence and in the presence of the essential oil of Myrtus communis leaves by gravimetric measurements and electrochemical measurements (potentiodynamic polarization and electrochemical impedance spectroscopy).

\section{Experimental}

\section{Plant material}

The essential oil used in this study is extracted from the leaves of Myrtus communis which were harvested in the Sidi Ahmed Cherif (Ouezzane, Morocco), and then dried in the shade in a dry and ventilated place for two weeks.

\section{Electrodes and chemicals and test solution}

Corrosion tests have been performed, using the gravimetric and electrochemical measurements, on electrodes cut from sheets of carbon steel with the chemical composition: $0.370 \% \mathrm{C}, 0.230 \% \mathrm{Si}, 0.680 \% \mathrm{Mn}, 0.016 \% \mathrm{~S}, 0.077 \% \mathrm{Cr}, 0.011 \% \mathrm{Ti}$, $0.059 \% \mathrm{Ni}, 0.009 \% \mathrm{Co}, 0.160 \% \mathrm{Cu}$, and the remainder iron. The aggressive medium of hydrochloric acid used for all studies were prepared by dilution of analytical grade $37 \%$ $\mathrm{HCl}$ with double distilled water. The concentrations of $\mathrm{MCO}$ used in this investigation were varied from $1,1.5,2,2.5 \mathrm{~g} / \mathrm{L}$. 


\section{Gravimetric measurements}

Gravimetric measurements were realized in a double walled glass cell equipped with a thermostat-cooling condenser. The mild steel specimens used have a rectangular form with dimension of $2.5 \times 2.0 \times 0.2 \mathrm{~cm}$ was abraded with a different grade of emery paper (320-800-1200) and then washed thoroughly with distilled water and acetone. After weighing accurately, the specimens were immersed in beakers which contained $100 \mathrm{ml}$ acid solutions without and with various concentrations of $\mathrm{MCO}$ at temperature equal to $303 \mathrm{~K}$ remained by a water thermostat for $6 \mathrm{~h}$ as immersion time. The gravimetric tests were performed by triplicate at same conditions. The corrosion rates $\left(C_{\mathrm{R}}\right)$ and the inhibition efficiency $\left(\eta_{w} \%\right)$ of mild steel have been evaluated from mass loss measurement using the following equations:

$$
\begin{gathered}
\eta_{\mathrm{W}}=\frac{C_{\mathrm{R}}-C_{\mathrm{R}}^{\prime}}{C_{\mathrm{R}}} \times 100 \\
\theta=1-\frac{C_{\mathrm{R}}^{\prime}}{C_{\mathrm{R}}} \Rightarrow \theta=\frac{\left(\eta_{\mathrm{W}} \%\right)}{100}
\end{gathered}
$$

where $C_{\mathrm{R}}$ and $C_{\mathrm{R}}^{\prime}$ are the corrosion rates of the mild steel in hydrochloric acid without and with the studied range of the MCO concentrations, respectively, $\theta$ is the degree of surface coverage.

\section{Electrochemical measurements}

Electrochemical measurements, including stationary methods (PDP) and transient (EIS) were performed in a three-electrode cell. Pure mild steel specimen was used as the working electrode, a saturated calomel (SCE) as reference and an area platinum as counter electrode (CE) were used. All potentials were measured against SCE. The working electrode was immersed in a test solution for $30 \mathrm{~min}$ until the corrosion potential of the equilibrium state $\left(E_{\text {corr }}\right)$ was achieved using a type PGZ100 potentiostat. The potentiodynamic polarization curves were determined by a constant sweep rate of $1 \mathrm{mV} / \mathrm{s}$. The measurements of the transitory method (EIS) were determined, using ac signals of amplitude $10 \mathrm{mV}$ peak to peak at different conditions in the frequency range of $100 \mathrm{kHz}$ to $10 \mathrm{mHz}$. The data obtained by EIS method were analyzed and fitted using graphing and analyzing impedance software, version Zview2. For PDP method, the inhibition efficiency of the studied compound was calculated using the following equation:

$$
\eta_{\mathrm{PDP}}(\%)=\left[1-\frac{i_{\text {corr }}}{i_{\text {corr }}^{0}}\right] \times 100
$$

where $i_{\text {corr }}$ and $i_{\text {corr }}^{0}$ are the corrosion rates in the presence and absence of inhibitor, respectively. The impedance diagrams were determined by EIS method. To confirm reproductibility, all experiments were repeated three times and the evaluated inaccuracy 
does not exceed $10 \%$. For EIS method, the inhibition efficiency was calculated using the following equation:

$$
\eta_{\mathrm{EIS}}(\%)=\left[\frac{R_{\mathrm{p}(\mathrm{inh})}-R_{\mathrm{p}}}{R_{\mathrm{p}(\text { inh })}}\right] \times 100
$$

where $R_{\mathrm{p}}$ and $R_{\mathrm{p} \text { (inh) }}$ were the polarisation resistance of mild steel electrode in the uninhibited and inhibited solutions, respectively.

\section{Results and discussion}

\section{Polarization results}

The effects of MCO on the corrosion reactions of mild steel in $1.0 \mathrm{M} \mathrm{HCl}$ solution were determined by polarization measurements. Figure 1 represents the potentiodynamic polarization curves of mild steel in $1.0 \mathrm{M} \mathrm{HCl}$ solution in the absence and presence of different concentrations of MCO. The PDP parameters including, corrosion current densities $\left(i_{\text {corr }}\right)$, corrosion potential $\left(E_{\text {corr }}\right)$, cathodic and anodic Tafel slopes $\left(\beta_{\mathrm{c}}\right.$ and $\left.\beta_{\mathrm{a}}\right)$ and corrosion inhibition efficiencies $\eta_{\mathrm{PDP}}$ were calculated and presented in Table 1.

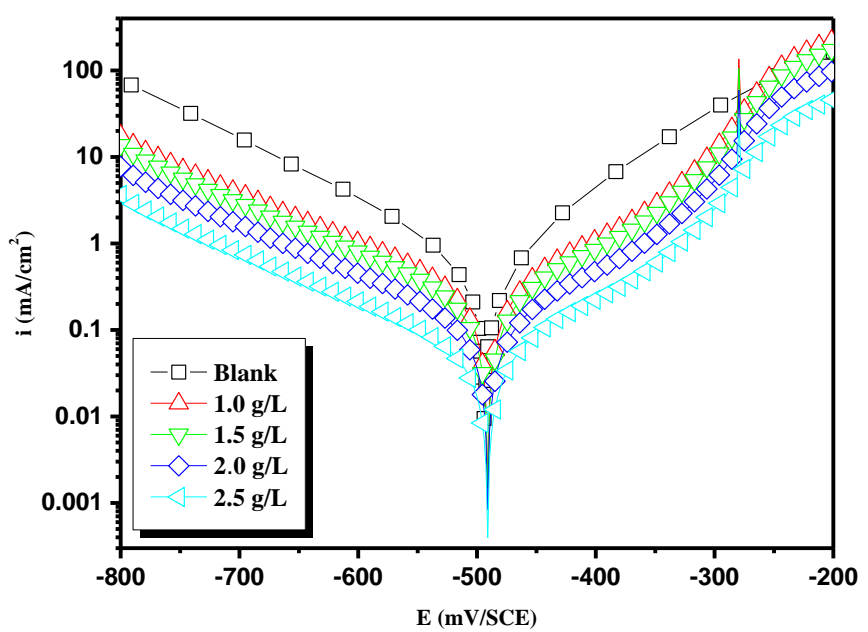

Figure 1. Potentiodynamic polarization curves for mild steel in $1 \mathrm{M} \mathrm{HCl}$ solution in the presence and absence of different concentrations of MCO at $303 \mathrm{~K}$.

As shown in Figure 1, the addition of MCO results in reducing both anodic and cathodic currents and without changes in the $E_{\text {corr }}$ value, indicating that $\mathrm{MCO}$ is a mixedtype inhibitor. Consequently, we can state that the mechanism of corrosion reactions does not change in presence of the inhibitor and the inhibition action is achieved by a simple blocking mechanism $[17,18]$. Thus, all the calculations in our study were based on this assumption. 
The inspection of Table 1 suggests that the values of corrosion current density $\left(i_{\text {corr }}\right)$ decreases more and more with increasing inhibitor concentrations. This observation suggests that $\mathrm{MCO}$ can effectively protect the MS dissolution in $1.0 \mathrm{M} \mathrm{HCl}$ solution $[19,20]$.

Table 1. The electrochemical parameters calculated by the PDP technique for the corrosion of mild steel in $1 \mathrm{M} \mathrm{HCl}$ in the absence and presence of different concentrations of $\mathrm{MCO}$ at $303 \mathrm{~K}$.

\begin{tabular}{ccccccc}
\hline Inhibitor & $\begin{array}{c}\text { Conc. } \\
(\mathbf{g} / \mathbf{L})\end{array}$ & $\begin{array}{c}-\underline{\boldsymbol{E}}_{\text {corr }} \\
(\mathbf{m V} / \mathbf{S C E})\end{array}$ & $\begin{array}{c}-\boldsymbol{\beta}_{\mathbf{c}} \\
\left(\mathbf{m V} \cdot \mathbf{d e c}^{-\mathbf{1}}\right)\end{array}$ & $\begin{array}{c}\boldsymbol{\beta}_{\mathbf{a}} \\
\left(\mathbf{m V} \cdot \mathbf{d e c}^{-\mathbf{1}}\right)\end{array}$ & $\begin{array}{c}\boldsymbol{i}_{\text {corr }} \\
\left(\boldsymbol{\mu} \mathbf{A} \cdot \mathbf{c m}^{-2}\right)\end{array}$ & $\begin{array}{c}\boldsymbol{\eta}_{\text {Tafel }} \\
(\boldsymbol{\%})\end{array}$ \\
\hline Blank & - & 496.0 & 162 & 113 & 564.0 & - \\
& 1.0 & 496 & 173 & 137 & 253 & 55 \\
\multirow{3}{*}{ MCO } & 1.5 & 495 & 171 & 140 & 193 & 65 \\
& 2.0 & 494 & 174 & 135 & 108 & 80 \\
& 2.5 & 493 & 175 & 141 & 47 & 91 \\
\hline
\end{tabular}

Electrochemical impedance spectroscopy (EIS)

Figure 2 represents the Nyquist plots for mild steel in the absence and presence of MCO in 1.0 $\mathrm{M} \mathrm{HCl}$ at $303 \mathrm{~K}$. It can be observed that all the impedance spectra obtained display one single depressed semicircle, which indicates that the corrosion process is related to the charge transfer process $[21,22]$. The depression in Nyquist semicircles may be due to frequency dispersion, inhomogeneities, and roughness of metal surface and substance transmission actions $[23,24]$. The similarity in the shapes of Nyquist plots in the absence and presence of inhibitor reveals that the corrosion mechanism is unaffected by the addition of the MCO. Furthermore, the diameter of the semicircles in the presence of MCO is very larger than that observed in uninhibited solution and increases with increasing inhibitor concentration, which may be due to the formation of protective film on mild steel surface and consequently reduction in corrosion rate [25].

The impedance spectra were analyzed by fitting to the equivalent circuit model shown in Figure 3, which has been used previously to adequately model the mild steel/acid interface [26,27]. Where $R_{\mathrm{S}}$ is the solution resistance, $R_{\mathrm{ct}}$ denotes the charge-transfer resistance and CPE is constant phase element. The introduction of CPE into the circuit was necessitated to explain the depression of the capacitance semicircle, which corresponds to surface heterogeneity resulting from surface roughness, impurities, and adsorption of inhibitors [28]. The impedance of this element is frequency-dependent and can be calculated using the Equation [29]:

$$
Z_{\mathrm{CPE}}=\frac{1}{Q(j \omega)^{n}}
$$




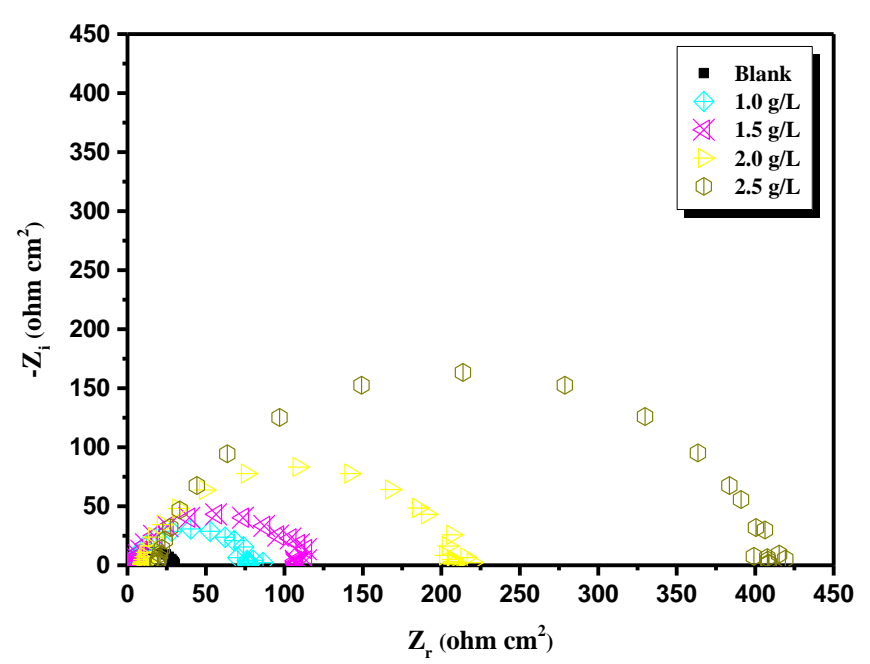

Figure 2. Nyquist plots for carbon steel in $1 \mathrm{M} \mathrm{HCl}$ solution containing various concentrations of $\mathrm{MCO}$ at $303 \mathrm{~K}$.

Where $Q$ is the CPE constant (in $\Omega^{-1} \cdot \mathrm{S}^{\mathrm{n}} \cdot \mathrm{cm}^{-2}$ ), $\omega$ is the angular frequency (in $\mathrm{rad} \cdot \mathrm{s}^{-1}$ ), $j^{2}=-1$ is the imaginary number and $n$ is a CPE exponent which can be used as a gauge for the heterogeneity or roughness of the surface [30,31]. In addition, the double layer capacitances, $C_{\mathrm{dl}}$, for a circuit including a CPE were calculated by using the following Equation 6:

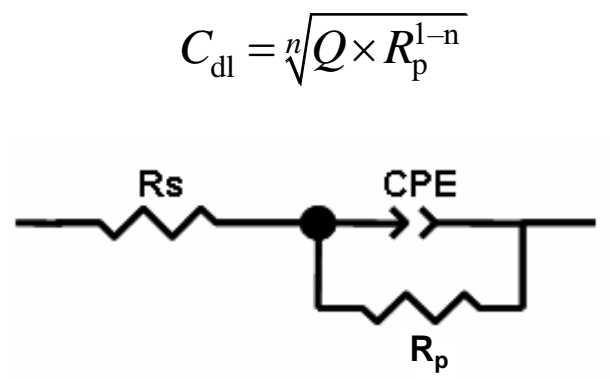

Figure 3. Equivalent electrical circuit.

Table 2. Impedance parameters recorded for mild steel electrode in $1 \mathrm{M} \mathrm{HCl}$ solution in the absence and presence of different concentrations of inhibitor at $298 \mathrm{~K}$.

\begin{tabular}{ccccccc}
\hline Inhibitor & $\begin{array}{c}\text { Conc. } \\
(\mathbf{g} / \mathbf{L})\end{array}$ & $\begin{array}{c}\boldsymbol{R}_{\mathbf{c t}} \\
\left(\boldsymbol{\Omega} \cdot \mathbf{c m}^{2}\right)\end{array}$ & $\boldsymbol{N}$ & $\begin{array}{c}\boldsymbol{Q} \cdot \mathbf{1 0}^{-4} \\
\left(\mathbf{s}^{\mathbf{n}} \cdot \mathbf{\Omega}^{\mathbf{- 1}} \cdot \mathbf{c m}^{-\mathbf{2}}\right)\end{array}$ & $\begin{array}{c}\boldsymbol{C}_{\mathbf{d l}} \\
\left(\boldsymbol{\mu} \mathbf{F} \cdot \mathbf{c m}^{-\mathbf{2}}\right)\end{array}$ & $\begin{array}{c}\boldsymbol{\eta}_{\mathbf{z}} \\
(\boldsymbol{\%})\end{array}$ \\
\hline Blank & - & 29.35 & 0.91 & 1.7610 & 91.63 & - \\
& 1.0 & 73 & 0.83 & 1.3539 & 52 & 59 \\
\multirow{3}{*}{ MCO } & 1.5 & 103 & 0.84 & 0.8755 & 35 & 71 \\
& 2.0 & 198 & 0.86 & 0.4548 & 21 & 85 \\
& 2.5 & 376 & 0.85 & 0.3761 & 17 & 92 \\
\hline
\end{tabular}


From results presented in Table 2, the polarization resistance, $R_{\mathrm{p}}$, increases gradually with concentration of inhibitor, which is accompanied of decrease in values of the double layer capacitance $C_{\mathrm{d}}$, suggests that the adsorption surface increases with concentration of the inhibitor and there by supply excellent barrier towards charge transfer reactions at the metal-solution interface [32]. The inhibition efficiency evaluated from $R_{\mathrm{p}}$ values are established the same trend determined from polarization experiments results.

\section{Adsorption isotherm}

Basic information on the interaction between the inhibitor and the MS surface can be provided by adsorption isotherm. The Langmuir model was found to be the best fit among various tested isotherms (Frumkin, Freundlich and Temkin) and consequently the good descriptor for adsorption of the MCO on the MS surface [33].

$$
\frac{C_{\text {inh }}}{\theta}=\frac{1}{K_{\text {ads }}}+C_{\text {inh }}
$$

Where $C_{\text {inh }}$ is the concentration, $K_{\text {ads }}$ is the equilibrium constant of the adsorption process. $K_{\text {ads }}$ are related to the standard free energy of adsorption $\Delta G_{\text {ads }}^{0}$ by the following equation [33]:

$$
\Delta G_{\mathrm{ads}}^{0}=-R T \ln \left(K_{\mathrm{ads}} \times 999\right)
$$

Where $R$ represents the gas constant and $T$ is the absolute temperature. The value of 999 is the concentration of water in solution in $\mathrm{g} / \mathrm{L}$.

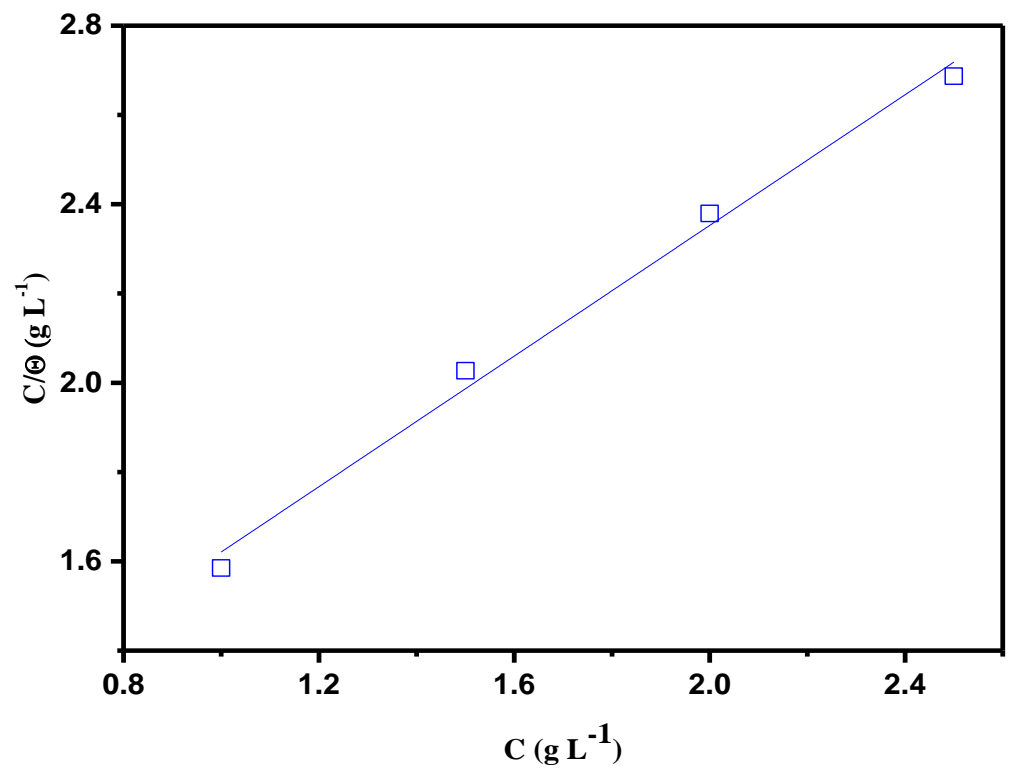

Figure 4. Langmuir adsorption of inhibitor on the mild steel surface in $1 \mathrm{M} \mathrm{HCl}$ solution at $303 \mathrm{~K}$. 
If we assume that the major component plays the principal role in inhibition, then adsorption obeys to Langmuir isotherm. But, generally in this kind of green inhibitors (natural plants: oil or extract), inhibitory action is related to the intermolecular synergistic effect if the various components of natural oil or extract [33]. It is safely recommended to not determine $\Delta G_{\text {ads }}^{0}$ value since the mechanism of adsorption remains unknown.

Weight loss study

\section{Effect of concentration}

Weight loss measurements of the MS in $1 \mathrm{M} \mathrm{HCl}$ in the absence and the presence of different concentrations of the studied inhibitor were carried out at $303 \mathrm{~K}$ and the results are reported in Table 3. As shown from the results, the corrosion rate of the MS decreased in the presence of the additive and the inhibition efficiency increased with an increase in the concentration of the inhibitor. The values of inhibition efficiencies calculated from the weight loss method are in good agreement with those calculated by the polarization and EIS methods.

Table 3. Effect of MCO concentration on corrosion data of mild steel in $1 \mathrm{M} \mathrm{HCl}$.

\begin{tabular}{ccccc}
\hline Inhibitor & $\begin{array}{c}\text { Conc. } \\
(\mathbf{g} / \mathbf{L})\end{array}$ & $\begin{array}{c}\boldsymbol{C}_{\mathbf{R}} \\
\left(\mathbf{m g} \cdot \mathbf{c m}^{-2} \cdot \mathbf{h}^{-\mathbf{1}}\right)\end{array}$ & $\begin{array}{c}\boldsymbol{\eta} \\
(\boldsymbol{\%})\end{array}$ & $\boldsymbol{\Theta}$ \\
\hline Blank & - & 1.135 & - & - \\
& 1.0 & 0.419 & 63 & 0.63 \\
\multirow{2}{*}{ MCO } & 1.5 & 0.295 & 74 & 0.74 \\
& 2.0 & 0.181 & 84 & 0.84 \\
& 2.5 & 0.079 & 93 & 0.93 \\
\hline
\end{tabular}

\section{Effect of the temperature}

Generally speaking, the impact of temperature on the corrosion process of metal in aggressive solution is complex, because many changes occur on the metal/solution interface, such as rapid etching, desorption of inhibitor and the decomposition or rearrangement of inhibitor itself [34-36]. In order to study the effect of temperature on the inhibition performance of MCO, weight loss measurements were performed in $1.0 \mathrm{M} \mathrm{HCl}$ in the absence and presence of $2.5 \mathrm{~g} / \mathrm{L}$ of inhibitor from 303 to $333 \mathrm{~K}$. Results obtained after $6 \mathrm{~h}$ exposure time are presented in Table 4. The results obtained from Table 4, reveal that the corrosion rate increased with increase in temperature in both uninhibited and inhibited solution. Also, the inhibition efficiency is observed to decrease with increase in temperature. 
Table 4. The results of the temperature effect of carbon steel corrosion performed in $1 \mathrm{M} \mathrm{HCl}$ and with $2 \mathrm{~g} / \mathrm{L}$ of MCO.

\begin{tabular}{ccccc}
\hline Inhibitor & $\begin{array}{c}\text { Temperature } \\
(\mathbf{K})\end{array}$ & $\begin{array}{c}\boldsymbol{C}_{\mathbf{R}} \\
\left(\mathbf{m g} \cdot \mathbf{c m}^{-\mathbf{2}} \cdot \mathbf{h}^{-\mathbf{1}}\right)\end{array}$ & $\begin{array}{c}\boldsymbol{\eta} \\
(\boldsymbol{\%})\end{array}$ & $\boldsymbol{\theta}$ \\
\hline \multirow{3}{*}{ Blank } & 303 & 1.135 & - & - \\
& 313 & 2.466 & - & - \\
& 323 & 5.032 & - & - \\
\hline \multirow{3}{*}{ MCO } & 333 & 10.029 & - & - \\
& 303 & 0.079 & 93 & 0.93 \\
& 313 & 0.301 & 87 & 0.87 \\
& 323 & 0.804 & 84 & 0.84 \\
\hline
\end{tabular}

The decrease in inhibition efficiency with temperature might be attributed to desorption of the inhibitor molecules from the metal surface at higher temperatures $[37,38]$.

The dependence of corrosion rate on temperature can be expressed by Arrhenius equation [39]:

$$
C_{\mathrm{R}}=A \exp \left(-\frac{E_{\mathrm{a}}}{R T}\right)
$$

Where $E_{\mathrm{a}}$ represents apparent activation energy, $R$ is the gas constant, $A$ is the preexponential factor. The values of $E_{\mathrm{a}}$ were calculated by linear regression between $\ln \left(C_{\mathrm{R}}\right)$ and 1/T (Figure 5). The value of $E_{\mathrm{a}}$ (Table 5) for inhibited solution is higher than that for uninhibited solution. The higher value of $E_{\mathrm{a}}$ in presence of inhibitor indicates that more energy barrier is required for the corrosion reaction to occur [40].

Thermodynamics of mild steel corrosion in $1 \mathrm{M} \mathrm{HCl}$ are calculated using an alternative formula of the Arrhenius equation [39]:

$$
C_{\mathrm{R}}=\frac{R T}{N h} \exp \left(\frac{\Delta S_{\mathrm{a}}}{R}\right) \exp \left(-\frac{\Delta H_{\mathrm{a}}}{R T}\right)
$$

Where $h$ is Planck's constant, $N$ is the Avogadro number, $R$ is the universal gas constant, $\Delta H_{\mathrm{a}}$ is the enthalpy of activation and $\Delta S_{\mathrm{a}}$ is the entropy of activation. Figure 6 shows that the Arrhenius plots of $\ln \left(C_{\mathrm{R}} / \mathrm{T}\right)$ versus $1 / \mathrm{T}$ gave straight lines with slope $\left(-\Delta H_{\mathrm{a}} / R\right)$ and intercept $\left(\ln (R) / \mathrm{N} h+\Delta S_{\mathrm{a}} / R\right)$ from where $\Delta H_{\mathrm{a}}$ and $\Delta S_{\mathrm{a}}$ values were calculated. 


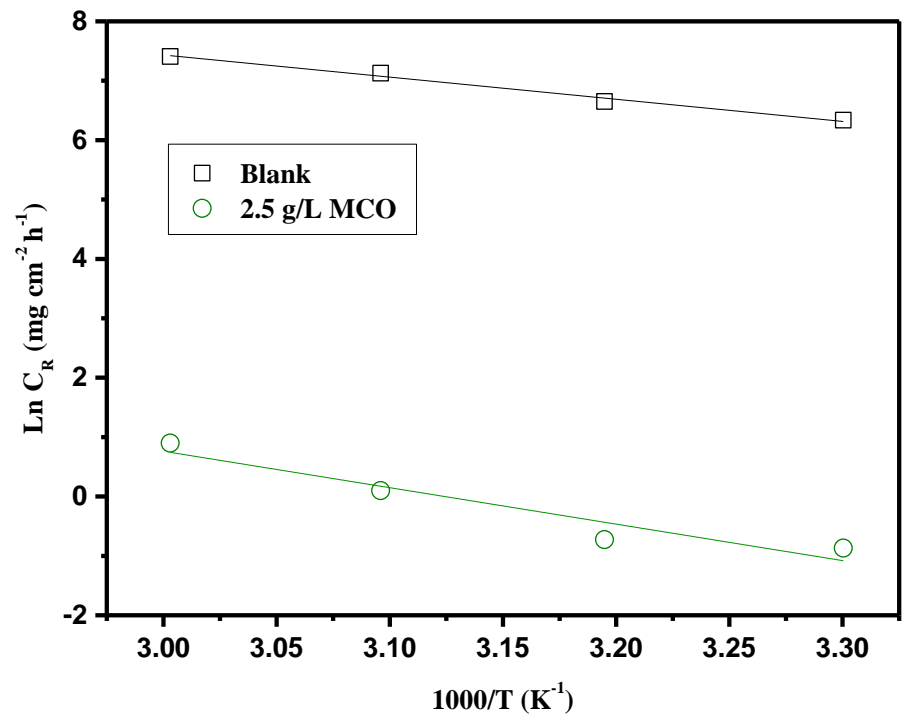

Figure 5. Arrhenius plots of $\ln \left(C_{\mathrm{R}}\right) v s .1 / \mathrm{T}$ for mild steel in $1 \mathrm{M} \mathrm{HCl}$ in the absence and the presence of $\mathrm{MCO}$ at optimum concentration.

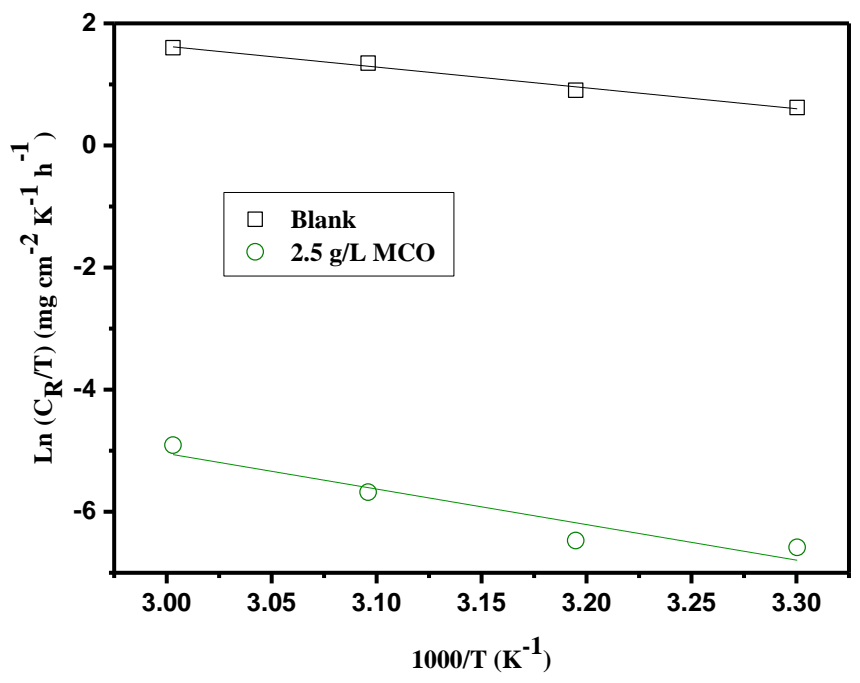

Figure 6. Relation between $\ln \left(C_{R} / T\right)$ and $1000 / T$ at different temperatures.

The positive values of $\Delta H_{\mathrm{a}}$ in the presence and absence of inhibitor reflect the endothermic nature of steel dissolution. The higher values of $\Delta S_{\mathrm{a}}$ might be the result of the adsorption of inhibitor molecules from the $1 \mathrm{M} \mathrm{HCl}$ solution, which could be regarded as a quasi-substitution process between these molecules in the aqueous phase and water molecules on the mild steel surface [41]. 
Table 5. Activation parameters for the mild steel dissolution in $1 \mathrm{M} \mathrm{HCl}$ in the absence and the presence of $2 \mathrm{~g} / \mathrm{L}$ of MCO.

\begin{tabular}{ccccc}
\hline Inhibitor & $\begin{array}{c}\boldsymbol{E}_{\mathbf{a}} \\
(\mathbf{k J} / \mathbf{m o l})\end{array}$ & $\begin{array}{c}\Delta \mathbf{H}_{\mathbf{a}} \\
(\mathbf{k J} / \mathbf{m o l})\end{array}$ & $\begin{array}{c}\Delta \mathbf{S}_{\mathbf{a}} \\
\left(\mathbf{J} \cdot \mathbf{m o l}^{-1} \cdot \mathbf{K}^{-\mathbf{1}}\right)\end{array}$ & $\boldsymbol{E}_{\mathbf{a}}-\Delta \boldsymbol{H}_{\mathbf{a}}$ \\
\hline Blank & 31.00 & 28.35 & -98.8 & 2.65 \\
$2.5 \mathrm{~g} / \mathrm{L} \mathrm{MCO}$ & 51.03 & 48.38 & 61.11 & 2.65 \\
\hline
\end{tabular}

\section{Conclusion}

From the results obtained we can be concluded that MCO acted as efficient corrosion inhibitor for mild steel in $1 \mathrm{M} \mathrm{HCl}$ solution. The polarization resistance $\left(R_{\mathrm{p}}\right)$ increases and the double layer capacitance $\left(C_{\mathrm{dl}}\right)$ decreases due to adsorption of the inhibitor molecules on the surface of mild steel. The polarization studies showed that the studied inhibitor acts as mixed inhibitor. The adsorption of the inhibitor on mild steel surface obeys the Langmuir adsorption isotherm.

\section{Acknowledgements}

We are grateful to Dr. LGAZ Hassane, Assistant Professor at the Department of Crop Science, Konkuk University, South Korea, for the support of this research.

\section{References}

1. M.H. Hussin and M.J. Kassim, Mater. Chem. Phys., 2011, 125, no. 3, 461-468. doi: 10.1016/j.matchemphys.2010.10.032

2. O.K. Abiola and A.O. James, Corros. Sci., 2010, 52, no. 2, 661-664. doi: 10.1016/j.corsci.2009.10.026

3. M. Messali, M. Larouj, H. Lgaz, N. Rezki, F.F. Al-Blewi, M.R. Aouad, A. Chaouiki, R. Salghi and Ill-Min Chung, Mol. Struct., 2018, 1168, 39-48. doi: 10.1016/j.molstruc.2018.05.018

4. A. Ostovari, S.M. Hoseinieh, M. Peikari, S.R. Shadizadeh and S.J. Hashemi, Corros. Sci., 2009, 51, no. 9, 1935-1949. doi: 10.1016/j.corsci.2009.05.024

5. O.K. Abiola and Y. Tobun, Chin. Chem. Lett., 2010, 21, no. 12, 1449-1452. doi: 10.1016/j.cclet.2010.07.008

6. H. Lgaz, R. Salghi, S. Jodeh and B. Hammouti, Effect of clozapine on inhibition of mild steel corrosion in 1.0 M HCl medium, J. Mol. Liq., 2017, 225, 271-280. doi: 10.1016/j.molliq.2016.11.039

7. M. Messali, H. Lgaz, R. Dassanayake, R. Salghi, S. Jodeh, N. Abidi and O. Hamed, J. Mol. Struct., 2017, 1145, 43-54. doi: 10.1016/j.molstruc.2017.05.081

8. R. Salghi, S. Jodeh, E.E. Ebenso, H. Lgaz, D. Ben Hmamou, M. Belkhaouda, I.H. Ali, M. Messali, B. Hammouti and S. Fattouch, Int. J. Electrochem. Sci., 2017, 12, 3283-3295. doi: $10.20964 / 2017.04 .46$ 
9. R.M. Saleh, A.A. Ismail and A.A. El Hosary, Br. Corros. J., 1982, 17, no. 3, 131-135. doi: $10.1179 / 000705982798274345$

10. P.B. Raja and M.G. Sethuraman, Mater. Lett., 2008, 62, no. 17-18, 2977-2979. doi: 10.1016/j.matlet.2008.01.087

11. N. Lahhit, A. Bouyanzer, J-M. Desjobert, B. Hammouti, R. Salghi, J. Costa, C. Jama, F. Bentiss and L. Majidi, Port. Electrochim. Acta, 2011, 29, no. 2, 127-138. doi: 10.4152/pea.201102127

12. A. Singh, K.R. Ansari, J. Haque, P. Doharec, H. Lgaz, R. Salghi and M.A. Quraishi, J. Taiwan Inst. Chem. Eng., 2018, 82, 233-251. doi: 10.1016/j.jtice.2017.09.021

13. B. Zerga, M. Sfaira, Z. Rais, M. Ebn Touhami, M. Taleb, B. Hammouti, B. Imelouane and A. Elbachiri, Mater. Tech., 2009, 97, no 5, 297-305. doi: $\underline{10.1051 / \mathrm{mattech} / 2009045}$

14. L. Bammou, B. Chebli, R. Salghi, L. Bazzi, B. Hammouti, M. Mihit and H. El Idrissi, Green Chem. Lett. Rev., 2010, 3, 173-178. doi: 10.1080/17518251003660121

15. A. Bouoidina, F. El-Hajjaji, M. Drissi, M. Taleb, B. Hammouti, Ill-Min Chung, S. Jodeh and H. Lgaz, Metall. Mater. Trans. A, 2018, 49, no. 10, 5180-5191. doi: 10.1007/s11661-018-4828-4

16. K. Boumhara, M. Tabyaoui, C. Jama and F. Bentiss, J. Ind. Eng. Chem., 2015, 29, 146-155. doi: 10.1016/j.jiec.2015.03.028

17. H. Lgaz, R. Salghi and S. Jodeh, Int. J. Corros. Scale Inhib., 2016, 5, no 4, 347-395. doi: $10.17675 / 2305-6894-2016-5-4-5$

18. I.A. Zaafarany and Hamza A. Ghulman, Int. J. Corros. Scale Inhib., 2013, 2, no. 2, 82-91. doi: 10.17675/2305-6894-2013-2-2-082-091

19. M.V. Fiori-Bimbi, P.E. Alvarez, H. Vaca and C.A. Gervasi, Corros. Sci., 2015, 92, 192-199. doi: $10.1016 /$ j.corsci.2014.12.002

20. A. Ehsani, M. Nasrollahzadeh, M.G. Mahjani, R. Moshrefi and H. Mostaanzadeh, $J$. Ind. Eng. Chem., 2014, 20, 4363-4370. doi: 10.1016/j.jiec.2014.01.045

21. D. Daoud, T. Douadi, S. Issaadi and S. Chafaa, Corros. Sci., 2014, 79, 50-58. doi: 10.1016/j.corsci.2013.10.025

22. I. Ahamad, R. Prasad and M.A. Quraishi, Corros. Sci., 2010, 52, no. 3, 933-942. doi: 10.1016/j.corsci.2009.11.016

23. P. Singh, A. Singh and M.A. Quraishi, J. Taiwan Inst. Chem. Eng., 2016, 60, 588-601.

24. N.A. Odewunmi, SA. Umoren and Z.M. Gasem, J. Environ. Chem. Eng., 2015, 3, 286-296. doi: $10.1016 /$ j.jece.2014.10.014

25. Nnabuk O. Eddy, H. Momoh-Yahaya and Emeka E. Oguzie, J. Adv. Res., 2015, 6, no. 2, 203-217. doi: 10.1016/j.jare.2014.01.004

26. A. Chaouiki, H. Lgaz, Ill Min Chung, I.H. Ali, S.L. Gaonkar, K.S. Bhat, R. Salghi, H. Oudda and M.I. Khan, J. Mol. Liq., 2018, 266, 603-616. doi: 10.1016/j.molliq.2018.06.103

27. M. Prabakaran, S-H. Kim, N. Mugila, V. Hemapriya, K. Parameswarib, S. Chitra and Ill-Min Chung, J. Ind. Eng. Chem., 2017, 52, 235-242. doi: 10.1016/j.jiec.2017.03.052 
28. K. Ramya, R. Mohan, K.K. Anupama and A. Joseph, Mater. Chem. Phys., 2015, 149150, 632-647. doi: $10.1016 /$ j.matchemphys.2014.11.020

29. CB. Verma, MA. Quraishi and A. Singh, J. Taiwan Inst. Chem. Eng., 2015, 49, 229-239. doi: $10.1016 / j . j t i c e .2014 .11 .029$

30. M.A. Amin, M.A. Ahmed, H.A. Arida, T. Arslan, M. Saracoglu and F. Kandemirli, Corros. Sci., 2011, 53, 540-548. doi: 10.1016/j.corsci.2010.09.019

31. M. Yadav, D. Behera, S. Kumar and R.R. Sinha, Ind. Eng. Chem. Res., 2013, 52, 6318-6328. doi: 10.1021/ie400099q

32. K. Khaled, Electrochim. Acta, 2008, 53, no. 9, 3484-3492. doi: 10.1016/j.electacta.2007.12.030

33. P. Mourya, S. Banerjee, R.B. Rastogi and M.M. Singh, Ind. Eng. Chem. Res., 2013, 52, 12733-12747. doi: $10.1021 /$ ie4012497

34. A.O. Yüce and G. Kardaş, Corros. Sci., 2012, 58, 86-94. doi: 10.1016/j.corsci.2012.01.013

35. H. Keleş, M. Keleş, I. Dehri and O. Serindag, Colloids Surf., A, 2008, 320, no. 1-3, 138-145. doi: $10.1016 /$ j.colsurfa.2008.01.040

36. X. Wang, H. Yang and F. Wang, Corros. Sci., 2011, 53, no. 1, 113-121. doi: 10.1016/j.corsci.2010.09.029

37. M. Mihit, S. El Issami, M. Bouklah, L. Bazzi, B. Hammouti, E. Ait Addi, R. Salghi and S. Kertit, Appl. Surf. Sci., 2006, 252, 2389-2395. doi: 10.1016/j.apsusc.2005.04.009

38. M. Mihit, K. Laarej, H. Abou El Makarim, L. Bazzi, R. Salghi and B. Hammouti, Arabian J. Chem., 2010, 3, 55-60. doi: 10.1016/j.arabjc.2009.12.009

39. C. Verma, L.O. Olasunkanmi, E.E. Ebenso, M.A. Quraishi and I.B. Obot, J. Phys. Chem. C, 2016, 120, 11598-11611. doi: 10.1021/acs.jpcc.6b04429

40. P. Singh, E.E. Ebenso, L.O. Olasunkanmi, I.B. Obot and M.A. Quraishi, J. Phys. Chem. C, 2016, 120, 3408-3419. doi: 10.1021/acs.jpcc.5b11901

41. I.B. Obot and N.O. Obi-Egbedi, Curr. Appl. Phys., 2011, 11, 382-392. doi: 10.1016/j.cap.2010.08.007 